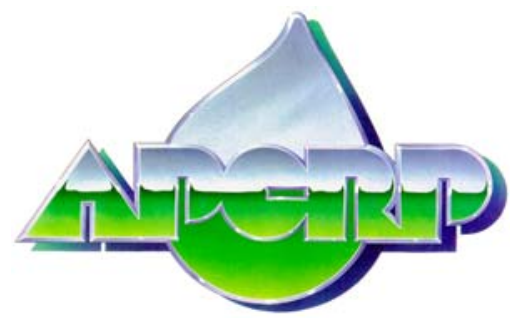

ERDC/TN APCRP-EA-15

April 2007

\title{
Contribution of Potamogeton crispus Decay to the Phosphorus Budget of McGinnis Lake, Wisconsin
}

by William F. James, Amy Dechamps, Nancy Turyk, and Paul McGinley

PURPOSE: This research evaluated the potential contribution of Potamogeton crispus (curly-leaf pondweed) senescence to the phosphorus budget of a small Wisconsin seepage lake.

BACKGROUND: Internal phosphorus loading (i.e., recycling of phosphorus stored in the sediment of lakes) represents an important source of nutrients for phytoplankton growth that needs to be considered in lake management plans that address phosphorus control. Phosphorus can be recycled from sediments via eH (i.e., oxidation-reduction) and $\mathrm{pH}$ reactions (Mortimer 1971, James et al. 1996), movement of groundwater through phosphorus-rich sediment (Brock et al. 1982), sediment phosphorus resuspension and boating activity (James and Barko 1994, James et al. 2003), and plant decomposition (Carpenter 1980). McGinnis Lake (Adams County, Wisconsin) is a small (13 ha) glacial seepage lake that currently exhibits mesoeutrophic conditions (total $\mathrm{P}=\sim 0.025 \mathrm{mg} \mathrm{L}^{-1}$; chlorophyll $=8-13 \mu \mathrm{g} \mathrm{L}^{-1}$ ). However, there is concern that internal phosphorus inputs by groundwater and by bottom sediment during periods of hypolimnetic anoxia may be contributing to algal blooms in the system. In addition, the nuisance macrophyte, Potamogeton crispus, occupies most shallow regions in the lake. The life cycle of this species is unusual because dieback occurs in mid-summer. Root uptake of phosphorus from the sediments by this plant, incorporation as tissue phosphorus, and senescence in mid- to late June can result in substantial recycling of phosphorus into the water column for phytoplankton uptake and growth during the middle of the growing season (James et al. 2003). In addition, metabolic activities (i.e., photosynthesis and respiration) of macrophyte communities can result in substantial diel variations in $\mathrm{eH}$ and $\mathrm{pH}$ that can indirectly enhance phosphorus flux from sediments, exacerbating internal phosphorus recycling to the water column. The objectives of this study were to quantify important phosphorus flux pathways in McGinnis Lake and to identify phosphorus control management activities that can reduce these inputs to the lake.

\section{METHODS}

Study Site. McGinnis Lake has two basins (lobes) connected by a narrow channel (Figure 1). The North lobe has an area of $\sim 4.6$ ha and a maximum depth of $8.5 \mathrm{~m}$. The South lobe has a much larger surface area ( $8.5 \mathrm{ha}$ ) and is shallow; maximum depth is $\sim 3 \mathrm{~m}$. No defined watershed tributary inflow to the lake exists and the hydrology of the system is dominated by groundwater seepage. The outflow is located in the South lobe and consists of a surface withdrawal structure. The lake is surrounded by permanent and seasonal residential homes that use septic systems. 


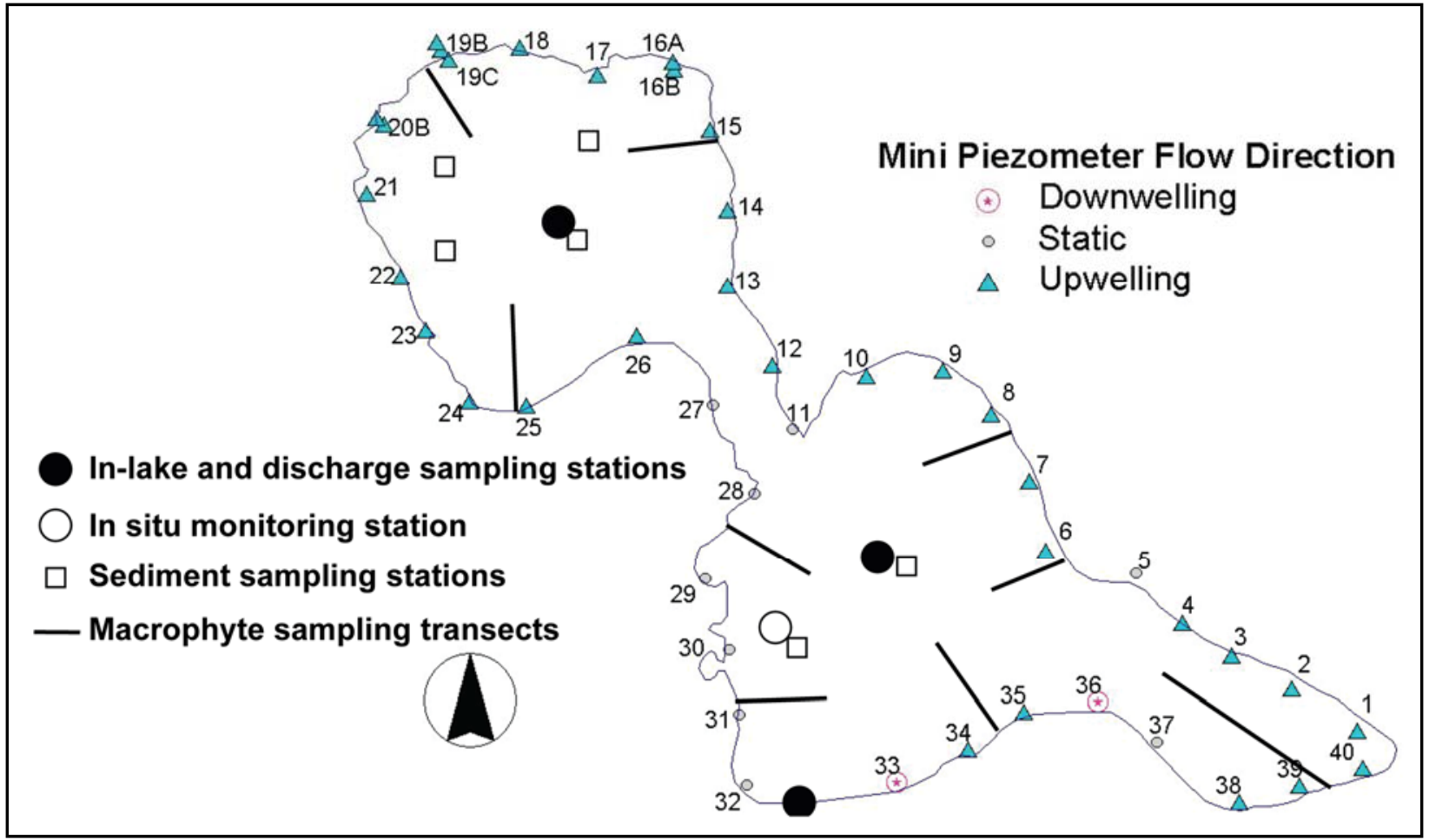

Figure 1. Map of McGinnis Lake showing sampling stations.

Hydrology. Water discharge from the lake through the outlet (Figure 1) was monitored continuously in 2002 using an ISCO 4150 area-velocity meter. Daily precipitation over the lake surface was measured at a station located next to the lake's outflow. Relative lake level was measured at 2-day intervals. Groundwater flow into McGinnis Lake was measured by the University of Wisconsin Stevens Point ${ }^{1}$ using mini-piezometer methodology. Forty sampling stations were established around the lake for measurement of groundwater upwelling and downwelling. Groundwater samples collected from the mini-piezometers were analyzed for soluble reactive phosphorus.

Routine Water Quality Monitoring. The University of Wisconsin - Stevens Point conducted a water quality monitoring study on McGinnis Lake at biweekly intervals between May and September 2002 (Figure 1). Sampling stations were established in the deep basin of the North lobe and in the approximate center of the South lobe for water sampling purposes. In situ measurements of temperature, dissolved oxygen, conductivity, and $\mathrm{pH}$ were collected at 2-ft depth intervals between the surface and bottom at each station. Secchi disk transparency was measured using an alternating black and white 10 -cm disk. Water samples for chemical analyses were collected $0.6 \mathrm{~m}$ below the lake surface, in the metalimnion, at the top of the hypolimnion, and immediately above the sediment surface in the North lobe. A composited water sample representing the entire water column was collected in the South lobe using an integrated sampler. Water samples were transported to the University of Wisconsin - Stevens Point in coolers on ice for analysis of the following variables (i.e., those used in this study) using standard analytical and automated techniques (American Public

\footnotetext{
${ }^{1}$ Personal Communication. 2003. A. DeChamps, N. Turyk, and P. McGinley, University of Wisconsin - Stevens Point.
} 
Health Association (APHA) 1998; Lachat Instruments, Hach Company, Lachat Division, Loveland, Colorado): total phosphorus, soluble reactive phosphorus, and chlorophyll. Samples for total phosphorus were digested with potassium persulfate before colorimetric analysis (Lachat Method $10-115-01-1-B)$. A portion of the water sample was filtered through a $0.45-\mu \mathrm{m}$ filter before determination of soluble reactive phosphorus. Chlorophyll was extracted using 90 percent acetone (APHA 1998). The trophic state index of McGinnis Lake was calculated using equations developed by Carlson (1977) and Lillie et al. (1993).

\section{Internal Sources of Phosphorus to the Lake.}

Phosphorus Release from Sediments. Triplicate cores were collected at seven stations distributed throughout the lake at differing depths (Figure 1). For each station, one sediment core was analyzed for phosphorus release under oxic conditions at $\mathrm{pH} \sim 8$, another core for phosphorus release under oxic conditions at $\mathrm{pH} \sim 9$, and a final core for phosphorus release under anoxic conditions.

A Wildco KB Sediment Core Sampler (Wildco Wildlife Supply Co.), equipped with an acrylic core liner (6.5-cm ID and 50-cm length), was used to collect sediment. The core liners, containing both sediment and overlying water, were immediately sealed using stoppers and stored in a protective box until analysis. Additional lake water was collected for incubation with the collected sediment.

In the laboratory, sediment cores were carefully drained of overlying water and the upper $10 \mathrm{~cm}$ of sediment was transferred intact to a smaller acrylic core liner $(6.5-\mathrm{cm}$ dia and $20-\mathrm{cm} \mathrm{ht})$ using a core remover tool. Lake water was filtered through a glass fiber filter (Gelman A-E), and $300 \mathrm{~mL}$ was siphoned onto the sediment contained in the small acrylic core liner without causing sediment resuspension. Sediment incubation systems consisted of the upper $10 \mathrm{~cm}$ of sediment and filtered overlying water contained in acrylic core liners that were sealed with rubber stoppers. The sediment incubation systems were placed in a darkened environmental chamber and incubated at a constant temperature $\left(20^{\circ} \mathrm{C}\right)$. The incubation temperature was set to a standard temperature for all stations for comparative purposes.

The oxidation-reduction environment in each system was controlled by gently bubbling either air (oxic) or nitrogen (anoxic) through an air stone placed just above the sediment surface. Higher $\mathrm{pH}$ was adjusted by bubbling core systems with carbon dioxide-free air. Bubbling action ensured complete mixing of the water column but did not disrupt the sediment. Control systems, containing only lake water, were incubated under the same redox and $\mathrm{pH}$ conditions.

Water samples for soluble reactive phosphorus (SRP) were collected daily from the center of each sediment incubation system using an acid-washed syringe and filtered through a $0.45-\mu \mathrm{m}$ membrane syringe filter (Nalge). The water volume removed from each system during sampling was replaced with filtered lake water preadjusted to the proper oxidation-reduction condition. SRP was determined colorimetrically using the ascorbic acid method (APHA 1998). Rates of phosphorus release from the sediment $\left(\mathrm{mg} \mathrm{m}^{-2} \mathrm{~d}^{-1}\right)$ were calculated as the linear change in concentration (corrected for dilution effects) in the overlying water divided by time and the area of the incubation core liner.

A station was established in the South lobe of the lake for determination of diel and seasonal variations in dissolved oxygen and $\mathrm{pH}$ in macrophyte beds that might impact rates of phosphorus release from sediments (Figure 1). YSI 6000 in situ water quality monitors (YSI Incorporated, Yellow 
Springs, Ohio) were deployed $0.25 \mathrm{~m}$ above the sediment and measurements were collected at 4-hr intervals between May and September. Deployed monitors were exchanged every two weeks with new, calibrated monitors. Both before and after deployment, the monitors were pre- and postcalibrated using Winkler titrations and $\mathrm{pH}$ buffers (APHA 1998). Before each deployment, the monitors and probes were cleaned and dissolved oxygen probes were serviced with new membranes.

Potamogeton crispus decomposition. The University of Wisconsin - Stevens Point conducted a survey to determine $P$. crispus biomass near the time of macrophyte scenescence in early June of 2002 using quadrat sampling techniques. Three transects were established randomly in the North lobe and six transects were established randomly in the South lobe, perpendicular to the shoreline (Figure 1). For sampling purposes, each transect was demarcated with a rope extending from the shoreline to the 6-ft depth. Each transect was stratified with respect to depth using the 0- to 3-ft and 3- to 6-ft depth contours. One sampling location was established within the 0 - to 3-ft depth contour and two sampling locations were established in the 3- to 6- $\mathrm{ft}$ depth contour. This sampling stratification scheme weighted the larger area encompassed by the 3 - to 6 -ft depth contour by $\sim 2 \mathrm{x}$. Stations were located by estimating the total distance between the two contours, then using a random number to determine the percent distance along the transect to sample.

The quadrat sampler measured $0.5 \mathrm{~m} \times 0.5 \mathrm{~m}$ and consisted of an enclosure $\sim 6 \mathrm{ft}$ tall. The sampler was lowered to the lake bottom to trap a known sediment surface area containing a macrophyte community. A rake was used to remove plant material from the sampler. On the boat, the cut material was gently rinsed to remove sediment and periphytin and sorted to determine $P$. crispus biomass only (other macrophytes were removed from the sample). $P$. crispus samples were rinsed in a dilute $(0.5 \mathrm{M})$ hydrochloric acid solution to remove calcium-carbonate and then weighed for fresh mass. Rinsed samples were brought back to the laboratory and dried at $40{ }^{\circ} \mathrm{C}$ to a constant weight for determination of an FW:DW conversion factor and percent tissue phosphorus. Tissue phosphorus analyses were performed by the University of Wisconsin - Stevens Point. Lake-wide mass, and mass of $P$. crispus in the North and South lobes of McGinnis Lake were estimated by weighting average biomass and phosphorus content with respect to area in each lobe. For the North lobe, P. crispus growth was assumed to be confined to the 2-m depth or less. For the South lobe, the entire area was used to estimate average $P$. crispus biomass. $P$. crispus decomposition, loss of tissue phosphorus, and internal phosphorus loading from this source were modeled using exponential decay equations developed by James et al. (2003) for P. crispus decomposition in Half Moon Lake, Wisconsin.

Phosphorus Loading Reduction Modeling. The water quality model Bathtub was used to assess current water quality conditions and the probable response of important water quality indicators (i.e., phosphorus, chlorophyll, Secchi transparency) to a reduction in phosphorus inputs to the lake (Walker 1996). The model used two lake compartments in order to assess lake responses to phosphorus loading reductions in the North and South lobes. The averaging period for the model was May through September.

\section{RESULTS AND DISCUSSION}

Phosphorus Sources to the Lake. Modest increases in discharge flow from McGinnis Lake were associated with several precipitation events that occurred during the summer period (Figure 2). Discharge flows were highest in May through June during a period of frequent precipitation and lower in July through September as a result of drier conditions. Relative lake elevation exhibited 
very minor peaks which coincided with precipitation events. Lakewide groundwater flow was estimated as the approximate base flow in the discharge from the lake (Figure 2). Groundwater flow was assumed constant during the study period. The summer hydrological balance indicated that groundwater and precipitation accounted for all of the water income to the lake (Table 1). Overland runoff was not measured directly during the study period. However, the hydrological balance indicated that this component was negligible to the water budget (Table 1).

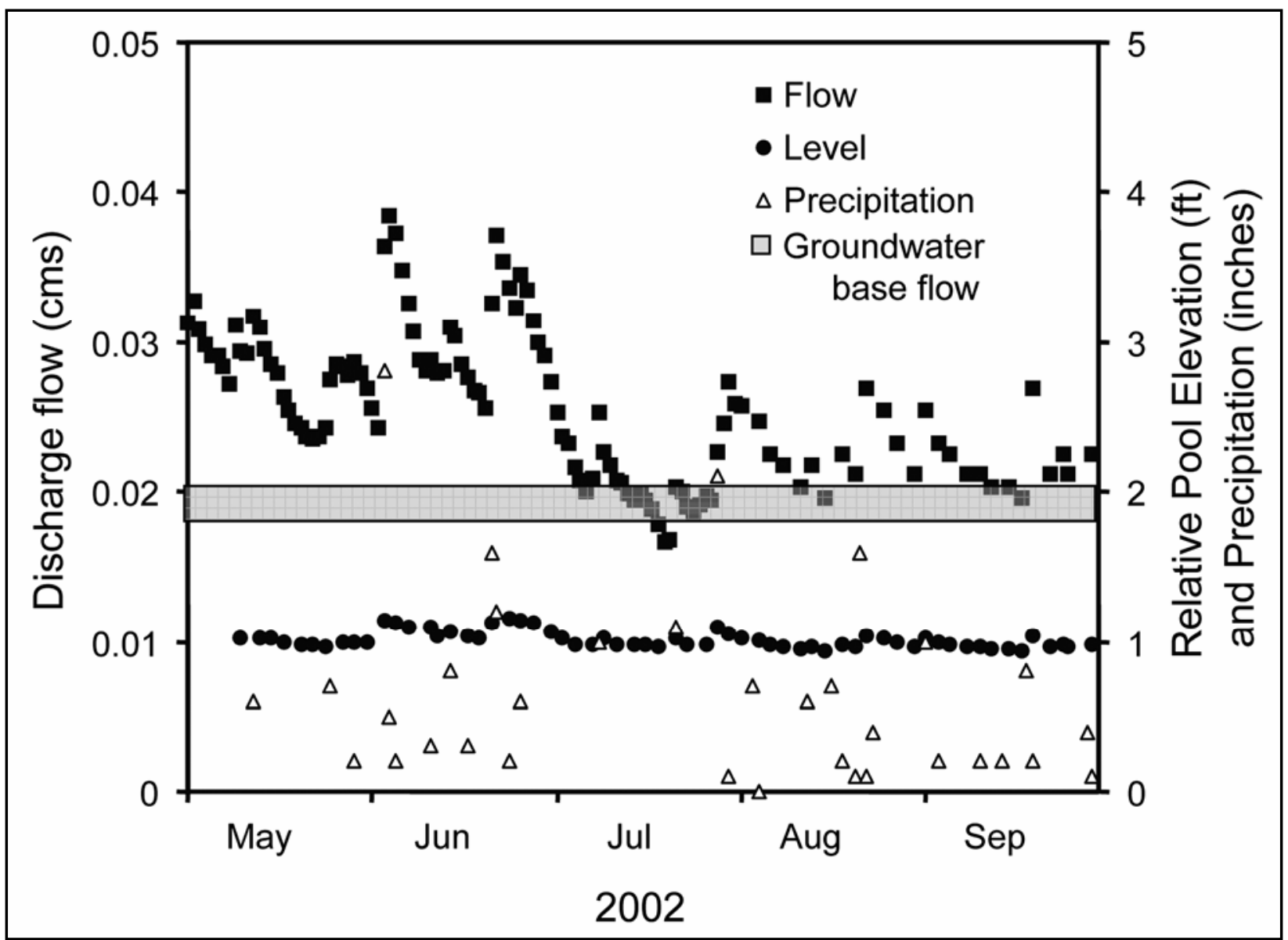

Figure 2. Seasonal variations in mean daily discharge flow, relative pool elevation, daily precipitation and groundwater base flow between May and September 2002.

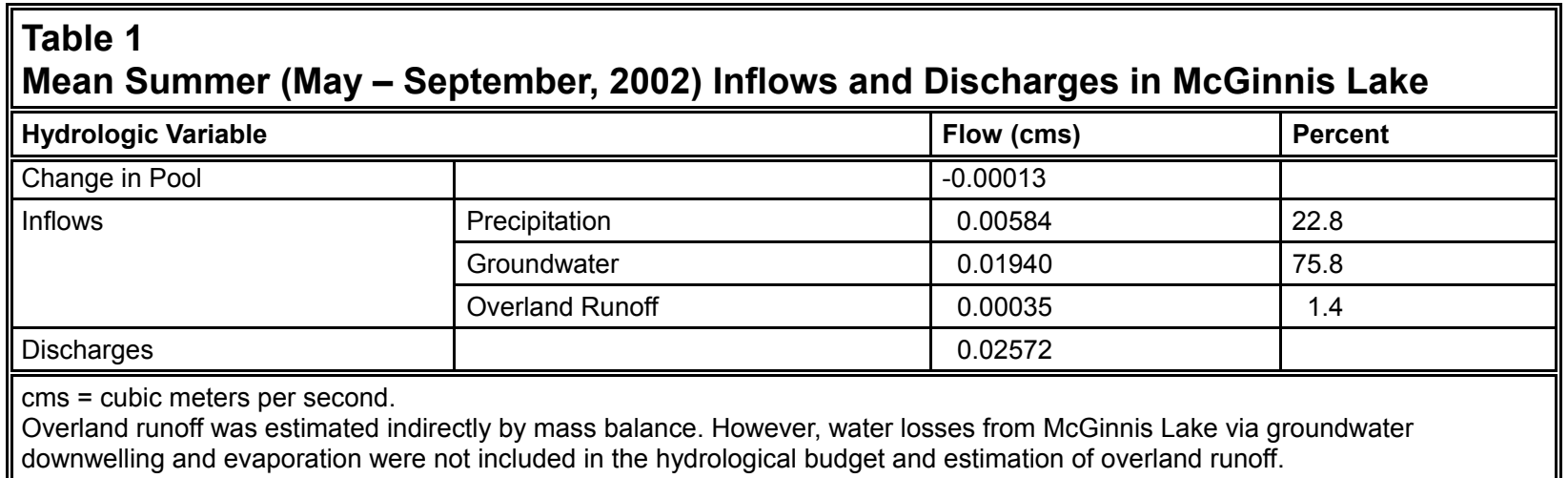


Discrete groundwater flows, measured by the University of Wisconsin - Stevens Point using minipiezometers, were greatest in the North lobe of McGinnis Lake and much lower in the South lobe (Figure 3). There was an inverse relationship between soluble reactive phosphorus concentration in the groundwater and groundwater flow velocity (Figure 3). Thus, higher groundwater flow velocities were associated with lower concentrations of soluble reactive phosphorus in the groundwater. The average groundwater soluble reactive phosphorus concentration entering the lake, weighted with respect to flow velocity, was $0.021 \mathrm{mg} \mathrm{L}^{-1}$.

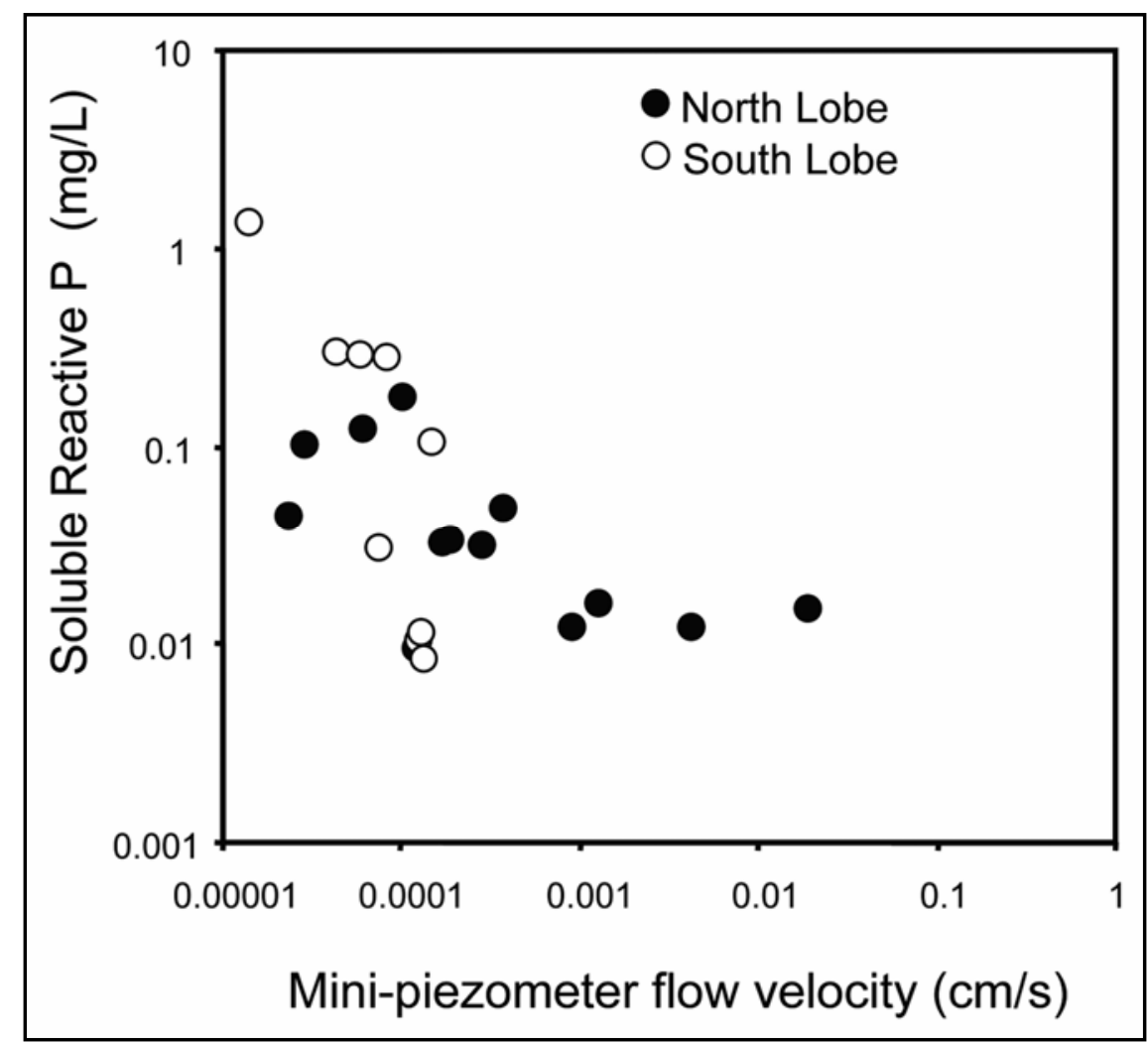

Figure 3. Relationship between mini-piezometer flow velocity and soluble reactive phosphorus $(P)$ concentration for McGinnis Lake.

The South lobe exhibited greater P. crispus biomass than the North lobe during the June survey (Table 2). However, P. crispus biomass was generally low throughout the lake. Leaching (defined as cellular autolysis) and decomposition (defined as fragmentation and bacterial breakdown) of $P$. crispus and flux of phosphorus to the water column were modeled using equations developed from another study (James et al. 2003). Leaching of phosphorus from plant tissue dominated breakdown during the early stages of senescence (Figure 4). The model suggested that nearly complete breakdown of senescing $P$. crispus occurred within 30 days. Overall, $\sim 6.8 \mathrm{~kg}$ of phosphorus in $P$. crispus biomass was potentially available for breakdown and release into the water column (primarily the South lobe) during senescence in the summer. 


\begin{tabular}{|c|c|c|c|}
\hline \multicolumn{4}{|c|}{$\begin{array}{l}\text { Table } 2 \\
\text { Estimates of } P \text {. crispus Phosphorus (P) Content Near the Time of } \\
\text { Peak Biomass (June) in the North and South Lobes of McGinnis } \\
\text { Lake }\end{array}$} \\
\hline Location & Biomass $\left(\mathrm{g} \mathrm{m}^{-2}\right)$ & P Content $\left(\mathrm{mg} \mathrm{m}^{-2}\right)$ & P Content (\%) \\
\hline North Lobe & 3.27 & 5.47 & \begin{tabular}{|l|l|}
1.67 \\
\end{tabular} \\
\hline South Lobe & 25.03 & 48.82 & 1.95 \\
\hline Lakewide & 17.37 & 33.56 & 1.93 \\
\hline
\end{tabular}

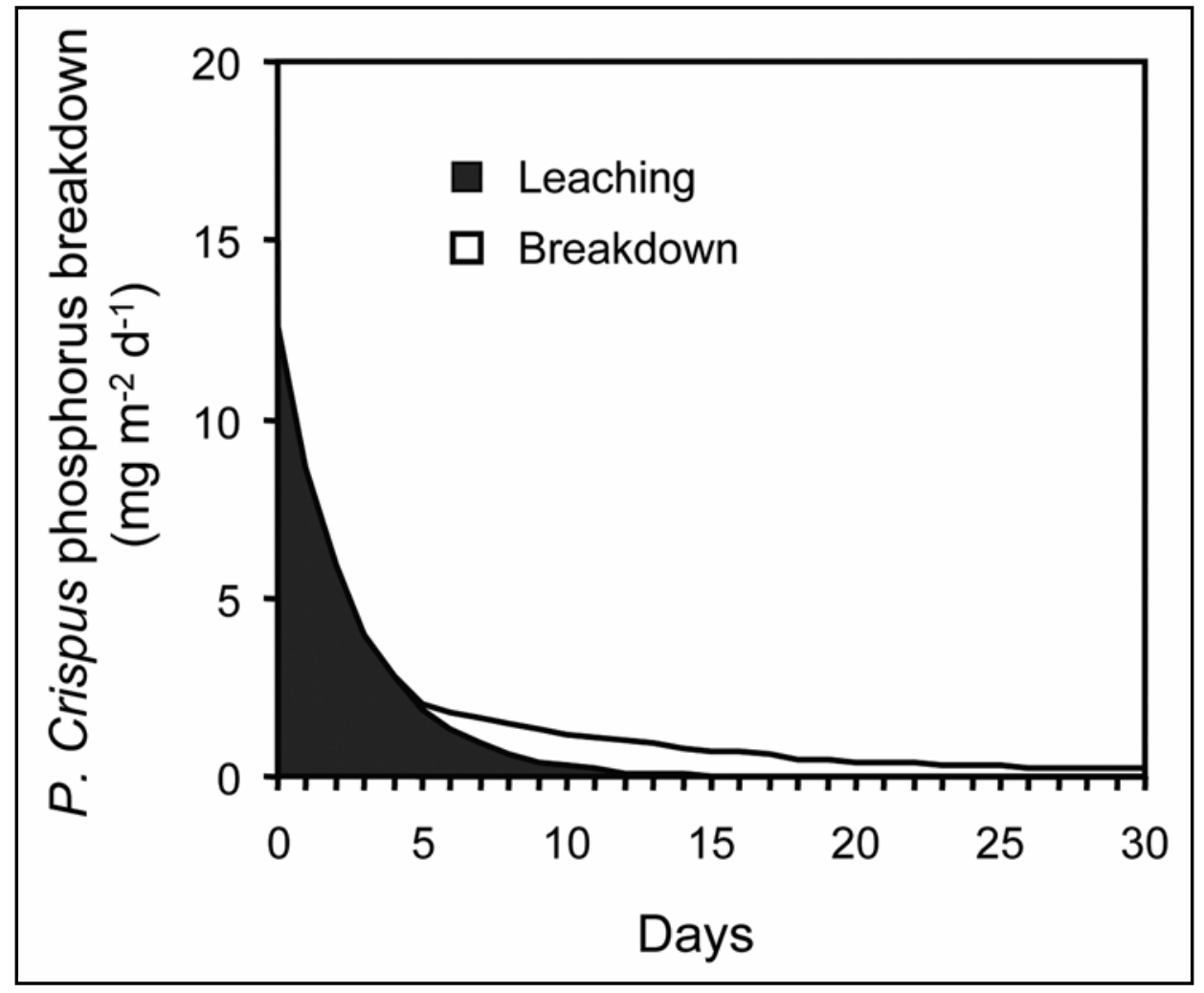

Figure 4. Loss of phosphorus via leaching (i.e., cellular autolysis) and breakdown (i.e., fragmentation and microbial metabolism) for Potamogeton crispus near the time of senescence in June.

Rates of phosphorus release from sediments in McGinnis Lake were regulated primarily by anoxic (i.e., no dissolved oxygen in the water due to bacterial respiratory demand), reducing conditions. Fluxes of phosphorus from the sediments were not detected under oxic conditions or at high $\mathrm{pH}$. There was a linear relationship between rates of phosphorus release from the sediments under anoxic conditions and depth below the lake surface (Figure 5). This depth-related pattern is typical for lakes and due to the seasonal erosion of fined-grained phosphorus-rich sediments from shallow regions of the lake and settling to deeper accumulation zones during periods of turnover (James et al. 2000). Anoxic rates of phosphorus release from sediments in the deep basin of the North lobe were very high at $>5 \mathrm{mg} \mathrm{m}^{-2} \mathrm{~d}^{-1}$, suggesting that sediments in this region were phosphorus-rich. When weighted with respect to depth, the overall rate of phosphorus release from sediments in the North 
lobe was $3.5 \mathrm{mg} \mathrm{m}^{-2} \mathrm{~d}^{-1}$, which was indicative of eutrophic sediments. Anoxic rates were lower at $\sim 2.7 \mathrm{mg} \mathrm{m}^{-2} \mathrm{~d}^{-1}$ for sediments collected in the shallow South lobe of the lake. However, this mean value was still within the range of rates found for eutrophic lakes.

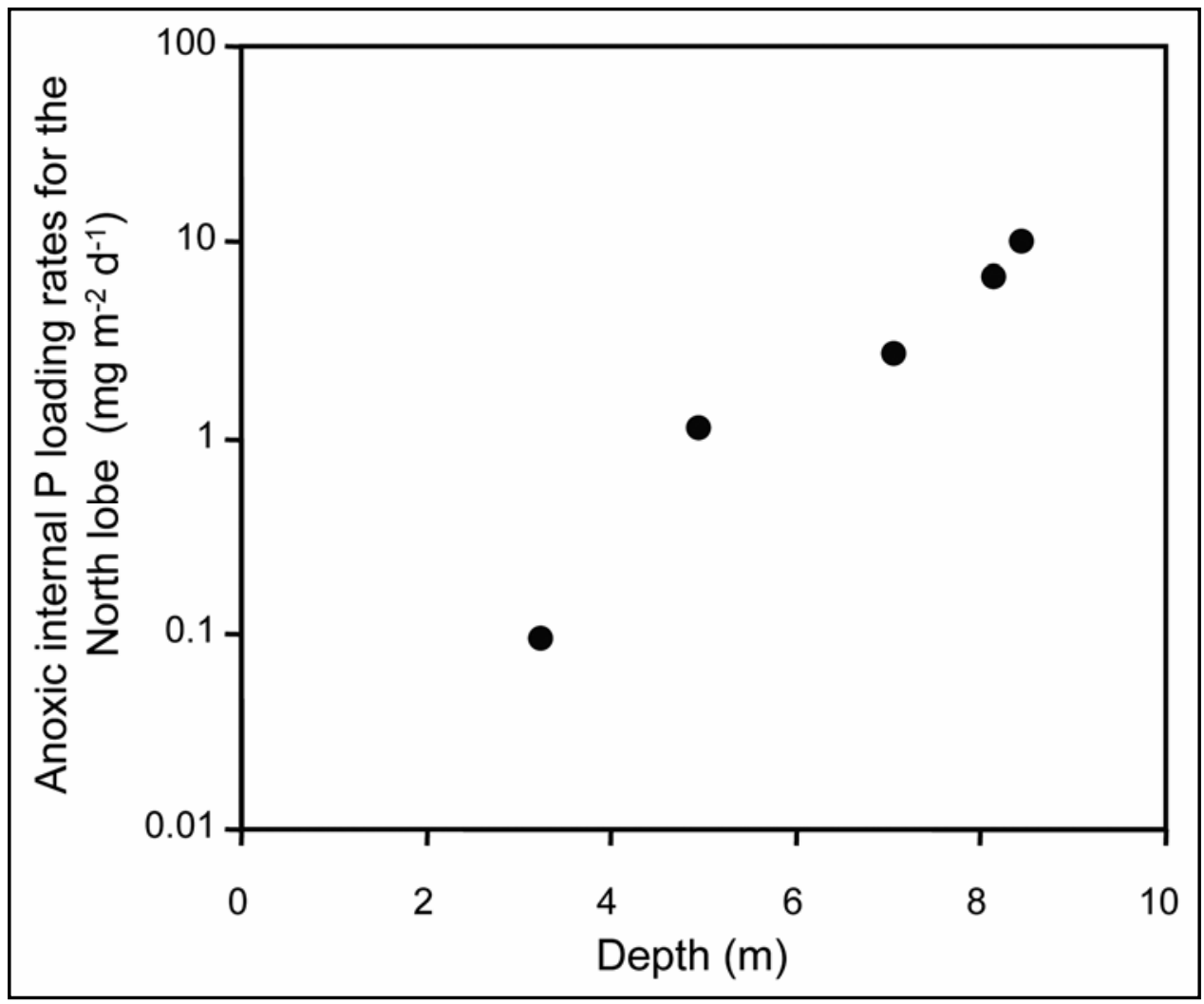

Figure 5. Variations in laboratory rates of internal phosphorus $(P)$ loading under anoxic conditions as a function of collection depth in the North lobe of McGinnis Lake.

Water Quality Patterns. The North lobe of McGinnis Lake exhibited strong thermal stratification during the summer period (Figure 6). Between the end of May and August, the epilimnion was confined to the upper $2 \mathrm{~m}$ depth of the lobe. Associated with thermal stratification was the development of anoxic conditions in the hypolimnion. Anoxia extended from the bottom to near the 3-m depth within the metalimnion between the end of May and September. 


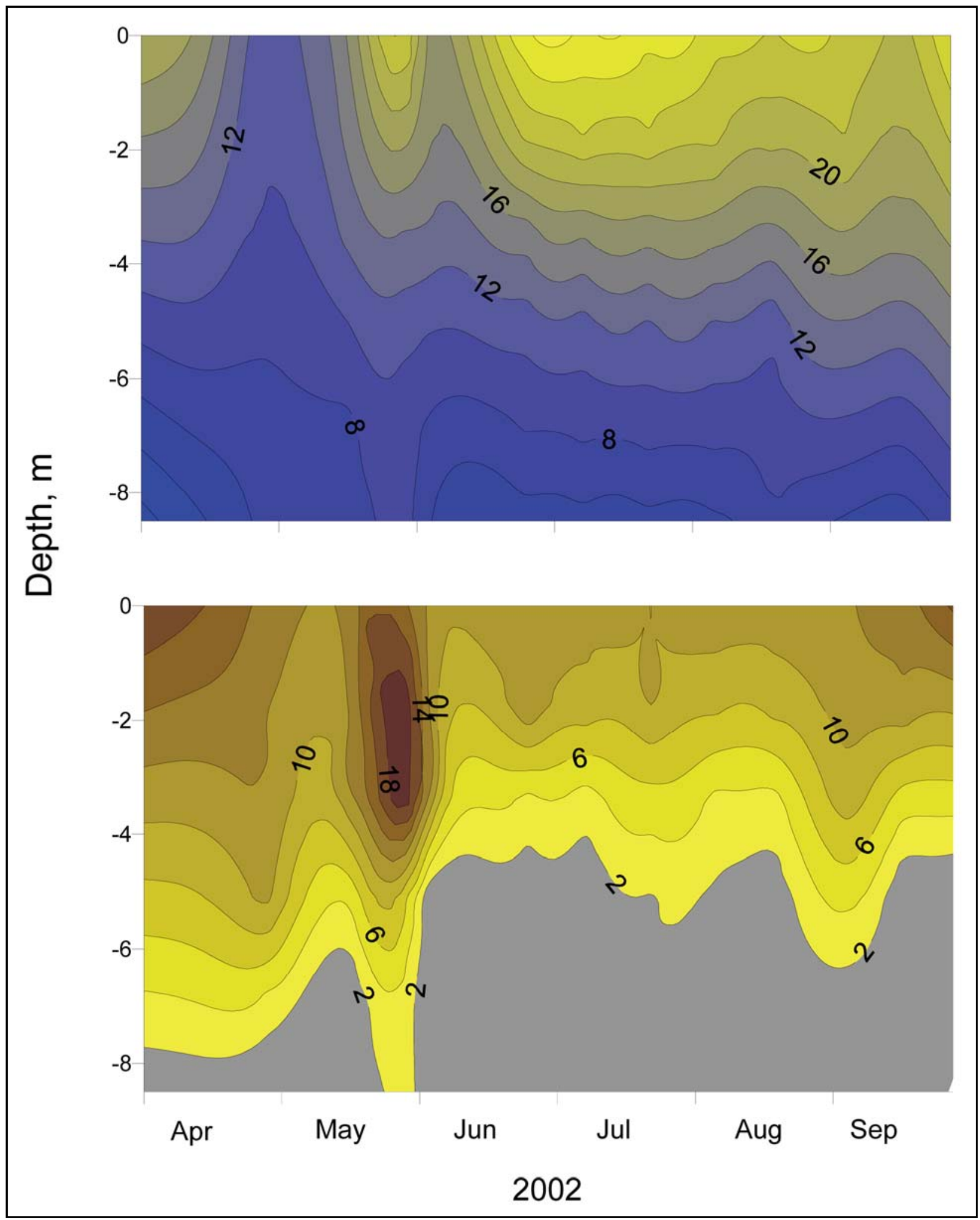

Figure 6. Contour plot of seasonal variations in (upper) temperature and (lower) dissolved oxygen in the North lobe of McGinnis Lake. Temperature contours are ${ }^{\circ} \mathrm{C}$ and dissolved oxygen contours are $\mathrm{mg} \mathrm{L}^{-1}$. Gray shaded areas represent dissolved oxygen concentrations $<2 \mathrm{mg} \mathrm{L}^{-1}$. Black areas represent dissolved oxygen concentrations near zero. 
In situ patterns of $\mathrm{pH}$ in the South lobe were high $(>10)$ during May, coincident with the seasonal growth period of $P$. crispus (Figure 7). Values declined and fluctuated near 9 in late June through early July. They declined to $<9$ in late July through early August, and increased to about 9 in late August. Diel fluctuations in $\mathrm{pH}$ were caused by net photosynthetic activities during the day that cause increases in $\mathrm{pH}$ and net respiratory activities at night that cause declines in $\mathrm{pH}$. Although high $\mathrm{pH}$ induced by macrophyte photosynthesis can indirectly enhance phosphorus release from sediment through ligand exchange (James et al. 1996), phosphorus release from sediments in McGinnis Lake, measured in the laboratory, were not found to be susceptible to high $\mathrm{pH}$ and ligand exchange processes. Thus, $\mathrm{pH}$ was not a factor in internal $\mathrm{P}$ loading from the sediments.

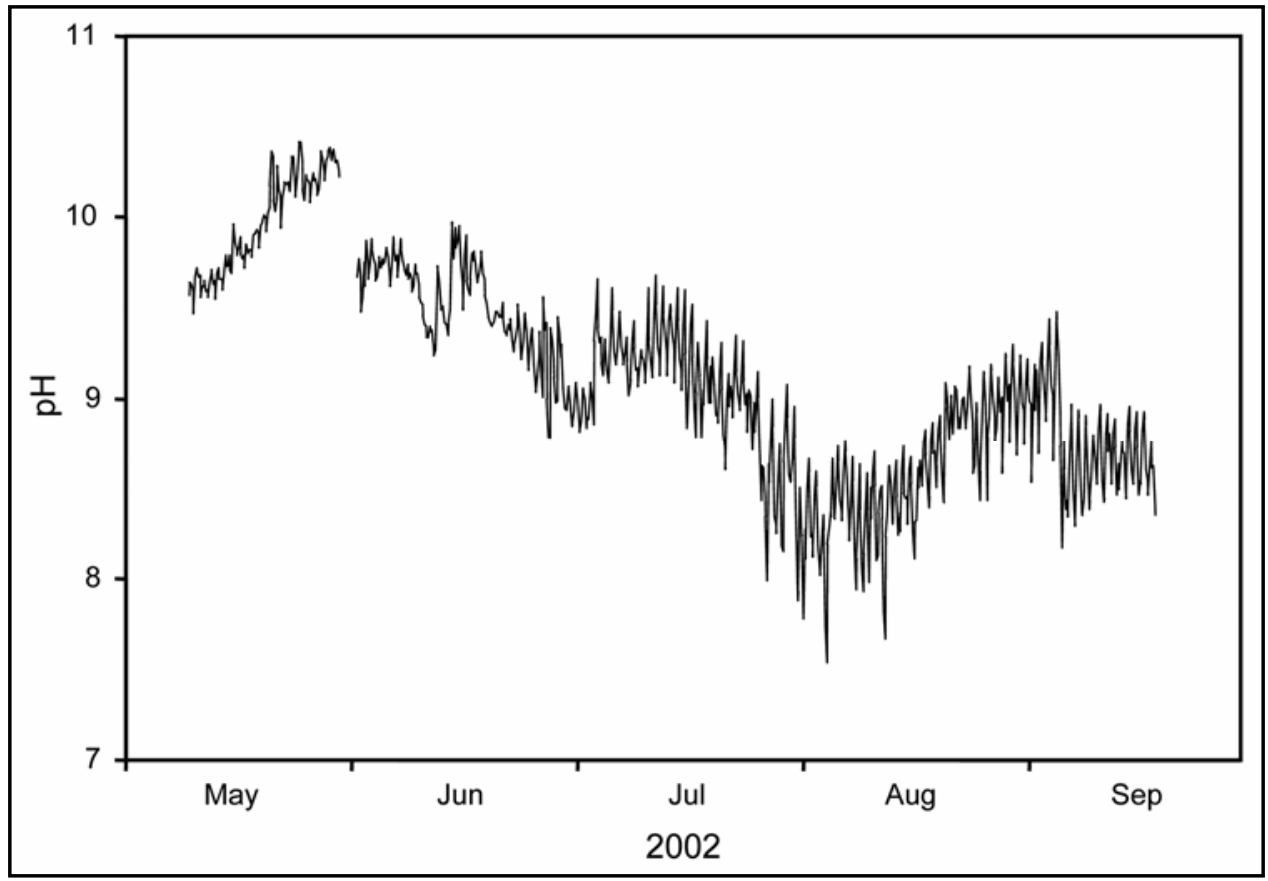

Figure 7. Diel and seasonal variations in in situ pH measured in the South lobe of McGinnis Lake between May and September 2002.

Dissolved oxygen concentrations in the South lobe were high in May, coincident with high $\mathrm{pH}$ and the occurrence of P. crispus growth (Figure 8). Concentrations declined in early June and approached anoxia at night on several days. Similar to $\mathrm{pH}$ patterns, dissolved oxygen fluctuated on a diel basis as a result of photosynthetic (i.e., increased concentration) and respiratory (i.e., decreased concentration) metabolic processes. Seasonal declines in dissolved oxygen and the occurrence of anoxic conditions at night on several occasions in June may have been attributed to the development of peak P. crispus biomass and the onset of its senescence. In July through September, dissolved oxygen concentrations exhibited a bimodal seasonal pattern. They exhibited a peak in July and September and a period of depressed concentrations in late July through early August. During the latter period, dissolved oxygen concentrations approached anoxic conditions on four nights. Internal P loading from sediments likely occurred in the South lobe of the lake under conditions of nighttime anoxia. 


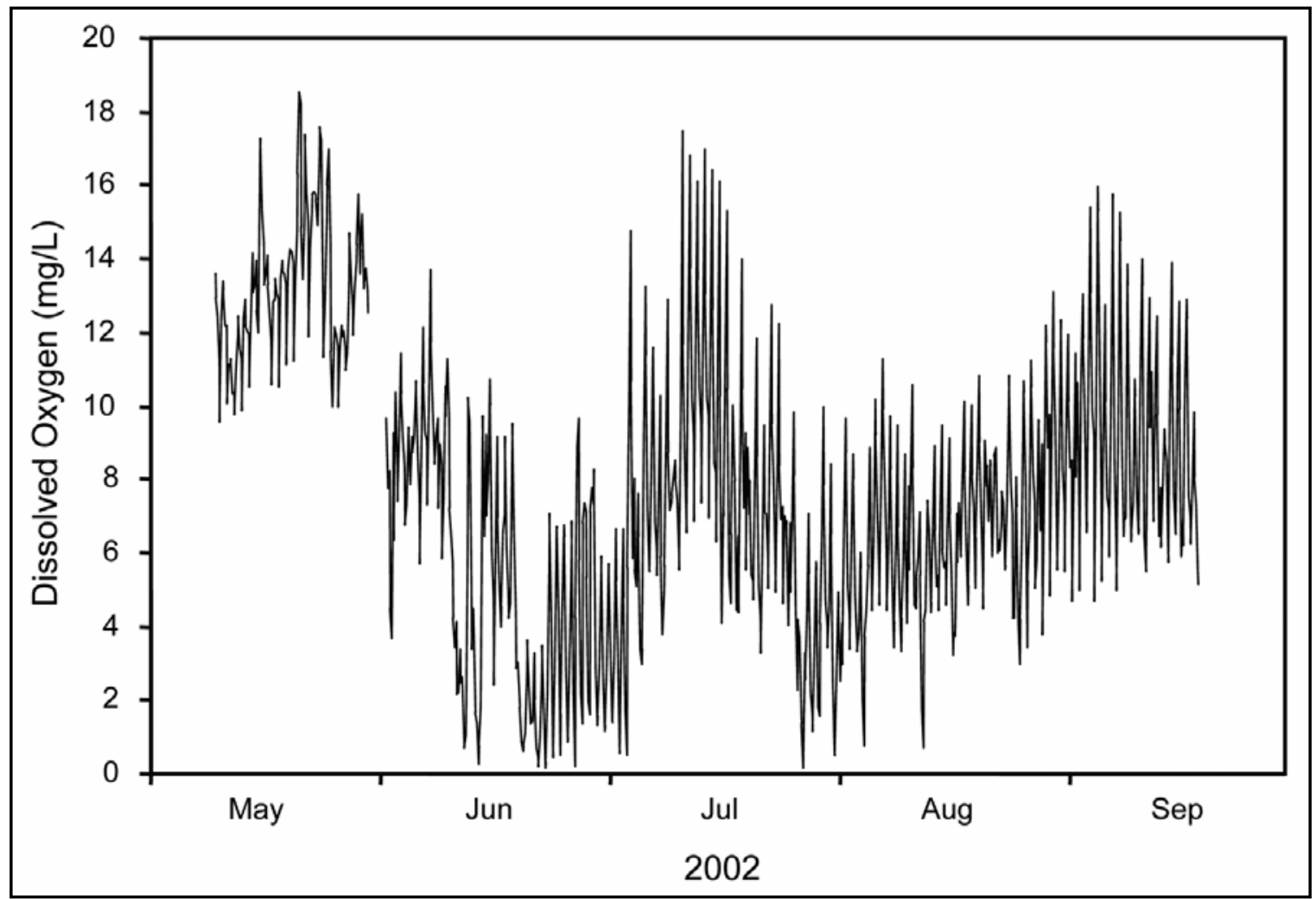

Figure 8. Diel and seasonal variations in in situ dissolved oxygen measured in the South lobe of McGinnis Lake between May and September 2002.

Coincident with stratification and hypolimnetic anoxia in the North lobe was the buildup of high concentrations of total phosphorus in the bottom waters, suggesting the occurrence of internal $\mathrm{P}$ loading via release from profundal sediment under anoxic conditions (Figure 9). Total phosphorus concentrations were much lower in the surface waters of the North lobe. In the South lobe, total phosphorus was also low (i.e., $<0.05 \mathrm{mg} \mathrm{L}^{-1}$ ). Chlorophyll concentrations were $<20 \mu \mathrm{g} \mathrm{L}^{-1}$ in the surface waters of the North lobe during the summer (Figure 9). The South lobe exhibited a concentration peak in early July which may have been associated with P. crispus decomposition and uptake of phosphorus leached from plant tissue for growth. However, bottom-dwelling filamentous algae were present at the time of sampling and may have contaminated the sample, biasing it toward a higher concentration than was actually present in the water column. During other sampling dates in the summer, the chlorophyll concentration was $<20 \mu \mathrm{g} \mathrm{L}{ }^{-1}$ in the South lobe.

Mean summer concentrations of total phosphorus, chlorophyll, Secchi transparency, and trophic state indicators (TSI) for the surface waters of the North and South lobes of McGinnis Lake are shown in Table 3. Overall, mean concentrations of chlorophyll and total phosphorus were low in both lobes. The TSI values for these variables between 40 and 60 indicated only moderately eutrophic conditions in the lake. Mean Secchi transparency was between $1.1 \mathrm{~m}$ and $1.6 \mathrm{~m}$. 


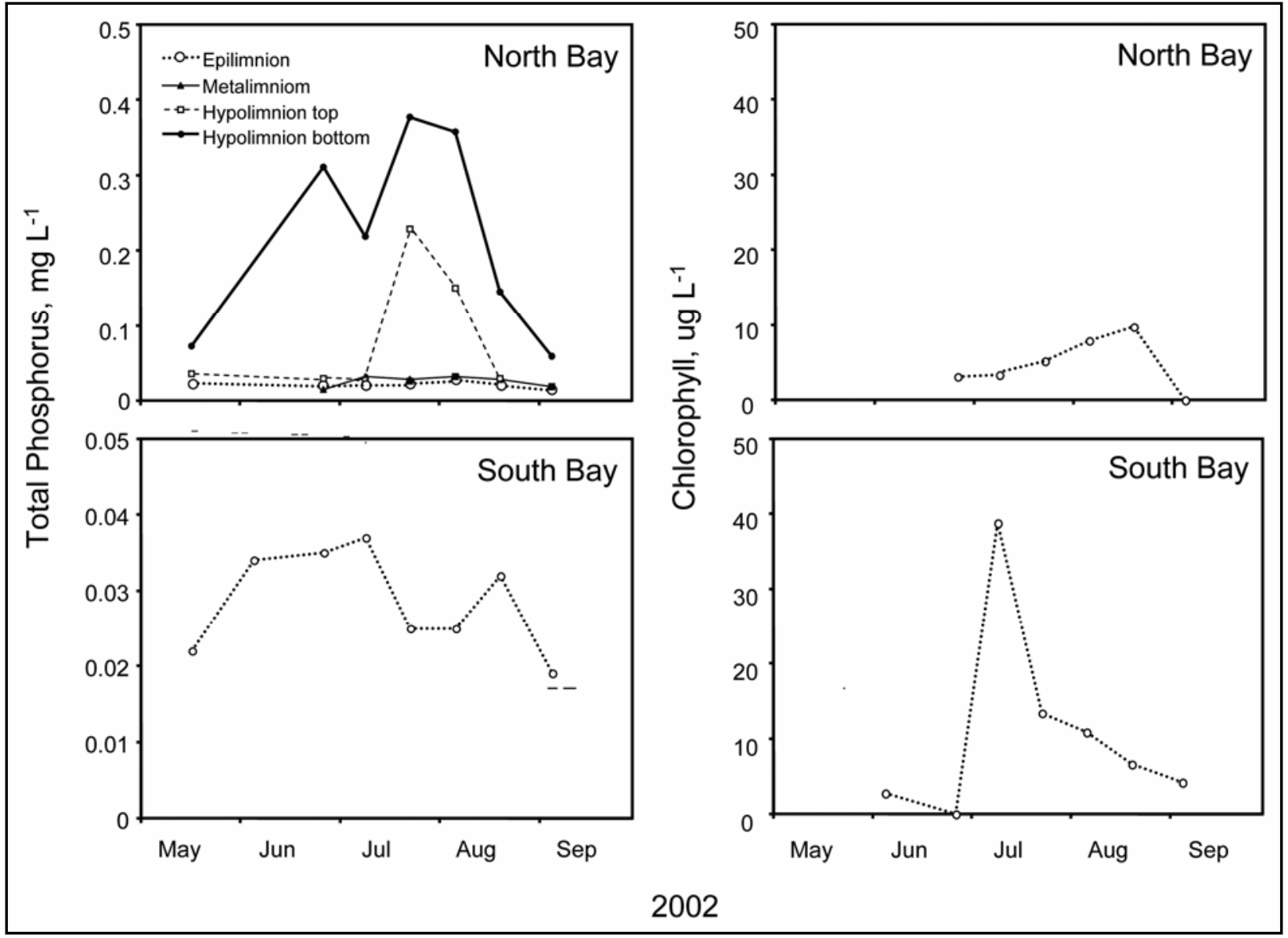

Figure 9. Seasonal variations in total phosphorus and chlorophyll at various depths in the North lobe and integrated over the entire water column in the South lobe of McGinnis Lake.

Table 3

Estimates of the Carlson and Wisconsin State Trophic Index (TSI) Values for the North and South Lobes of McGinnis Lake During the Summer (May-September) $2002^{1}$

\begin{tabular}{|c|c|c|c|c|c|c|c|c|c|}
\hline \multirow[b]{2}{*}{ Location } & \multirow[b]{2}{*}{$S D(m)$} & \multirow[b]{2}{*}{ Chla $\left(\mu \mathrm{g} \mathrm{L}^{-1}\right)$} & \multirow[b]{2}{*}{$\mathrm{TP}\left(\mathrm{mg} \mathrm{L}^{-1}\right)$} & \multicolumn{3}{|c|}{ Carlson TSI } & \multicolumn{3}{|c|}{ Wisconsin TSI } \\
\hline & & & & $\mathrm{TSI}_{\mathrm{SD}}$ & $\mathrm{TSI}_{\mathrm{CHLA}}$ & $\mathrm{TSI}_{\mathrm{TP}}$ & $\mathrm{TSI}_{\mathrm{SD}}$ & TSI ${ }_{\text {CHLA }}$ & $\mathrm{TSI}_{\mathrm{TP}}$ \\
\hline North lobe & 1.6 & 8.00 & 0.023 & 53.4 & 50.5 & 52.4 & 53.2 & 51.0 & 49.4 \\
\hline South lobe & 1.1 & 12.76 & 0.029 & 58.7 & 54.1 & 54.2 & 58.6 & 55.5 & 52.7 \\
\hline
\end{tabular}

Phosphorus Budgetary Analysis. The above observations were used to construct a phosphorus budget for the lake (Table 4). Inputs to the lake included phosphorus from direct precipitation over the lake $\left(\mathrm{P}_{\text {precipitation }}\right)$, groundwater $\left(\mathrm{P}_{\text {groundwater }}\right)$, P. crispus decomposition during the summer $\left(\mathrm{P}_{\text {plant decomposition }}\right)$, and phosphorus release from sediments and movement into the water column ( $\left.\mathrm{P}_{\text {sediment }}\right)$. The measured output from the lake was phosphorus discharge from the outlet structure $\left(\mathrm{P}_{\text {discharge }}\right)$. Phosphorus discharge from the lake via groundwater downwelling was assumed to be 
negligible. Using a mass balance approach, sedimentation of particulate phosphorus $\left(\mathrm{P}_{\text {deposition }}\right)$ in the lake was calculated as:

$$
\Delta P_{\text {lake }}=\left(P_{\text {precipitation }}+P_{\text {groundwater }}+P_{\text {plant decomposition }}+P_{\text {sediment }}\right)-\left(P_{\text {deposition }}+P_{\text {discharge }}\right)
$$

where $\Delta \mathrm{P}_{\text {lake }}$ is the change in phosphorus mass in the water column. All fluxes were normalized with respect to a 153-day summer period (i.e., May through September) and the surface area of the North lobe, the South lobe, or the entire lake. For instance, $P$. crispus phosphorus fluxes to the lake via decomposition occurred over a 30-day period between late June and July. However, during the other 123 days of the summer period (i.e., May through September), phosphorus fluxes from this source were assumed to be zero. Thus, the overall phosphorus flux from this source was adjusted to account for periods of zero flux as well as flux via decomposition during the May through September averaging period.

\section{Table 4}

Sources and Sinks of Phosphorus (P) to the Epilimnion of McGinnis Lake During the Summer (May-September) Period 2002

\begin{tabular}{|c|c|c|c|c|c|}
\hline \multicolumn{2}{|l|}{ Flux } & $\begin{array}{l}\text { North lobe rate } \\
\left(\mathrm{mg} \mathrm{m}^{-2} \mathrm{~d}^{-1}\right)\end{array}$ & $\begin{array}{l}\text { South lobe rate } \\
\left(\mathrm{mg} \mathrm{m}^{-2} \mathrm{~d}^{-1}\right)\end{array}$ & $\begin{array}{l}\text { Lake-wide rate } \\
\left(\mathrm{mg} \mathrm{m}^{-2} \mathrm{~d}^{-1}\right)\end{array}$ & $\begin{array}{l}\text { Lake-wide mass } \\
(\mathrm{kg})\end{array}$ \\
\hline \multirow[t]{5}{*}{$P$ inputs } & Precipitation & 0.11 & 0.11 & 0.11 & 2.2 \\
\hline & Groundwater & 0.59 & 0.08 & 0.26 & 5.3 \\
\hline & Plant decomposition & 0.05 & 0.50 & 0.34 & 6.8 \\
\hline & Bottom sediment & $0.16^{1}$ & 0.08 & 0.11 & 3.6 \\
\hline & Overland runoff & 0 & 0 & 0 & 0 \\
\hline P output & Discharge & & & 0.62 & 12.5 \\
\hline
\end{tabular}

For the South lobe, $\mathrm{P}_{\text {sediment }}$ was assumed to be zero during periods when dissolved oxygen was $\geq 1 \mathrm{mg} \mathrm{L}^{-1}$ and $\sim 2.7 \mathrm{mg} \mathrm{m}^{-2} \mathrm{~d}^{-1}$ when dissolved oxygen conditions in the lobe were $<1 \mathrm{mg} \mathrm{L}^{-1}$, based on an analysis of in situ dissolved oxygen patterns in the lobe (Figure 8). Anoxia occurred in the South lobe $\sim 3$ percent of the time during the summer period. For the North lobe, an attempt was made to estimate the vertical flux of phosphorus from the hypolimnion into the surface waters during the summer, as not all phosphorus originating from the bottom sediments will be transported vertically into the surface waters for uptake by algae in a stratified system. Observations of phosphorus concentrations in the surface waters and bottom waters during the summer period (Figure 10) and information on fluxes of phosphorus from other sources (i.e., the phosphorus mass balance Equation 1) applied to the North lobe of McGinnis Lake were used to compute an upward phosphorus flux of $\sim 0.16 \mathrm{mg} \mathrm{m}^{-2} \mathrm{~d}^{-1}$ from the hypolimnion into the epilimnion during the summer.

The dominant phosphorus input to the North lobe was from groundwater ( 59 percent), which reflected groundwater flow patterns to this region of the lake (Table 4). Even though phosphorus flux from bottom sediments was high in the North lobe and anoxic conditions occurred in the hypolimnion during most of the summer period, only about 5 percent of this phosphorus was estimated to be transported into the surface waters for potential uptake by algae. Thus, $\mathrm{P}_{\text {sediment }}$ represented about 
16 percent of the overall phosphorus inputs to the North lobe. Phosphorus fluxes via $\mathrm{P}_{\text {plant decomposition }}$ accounted for $<15$ percent of the total phosphorus input to the lake because $P$. crispus biomass was very low in this region. $\mathrm{P}_{\text {precipitation }}$ only accounted for $\sim 11$ percent of the phosphorus budget of the North lobe.

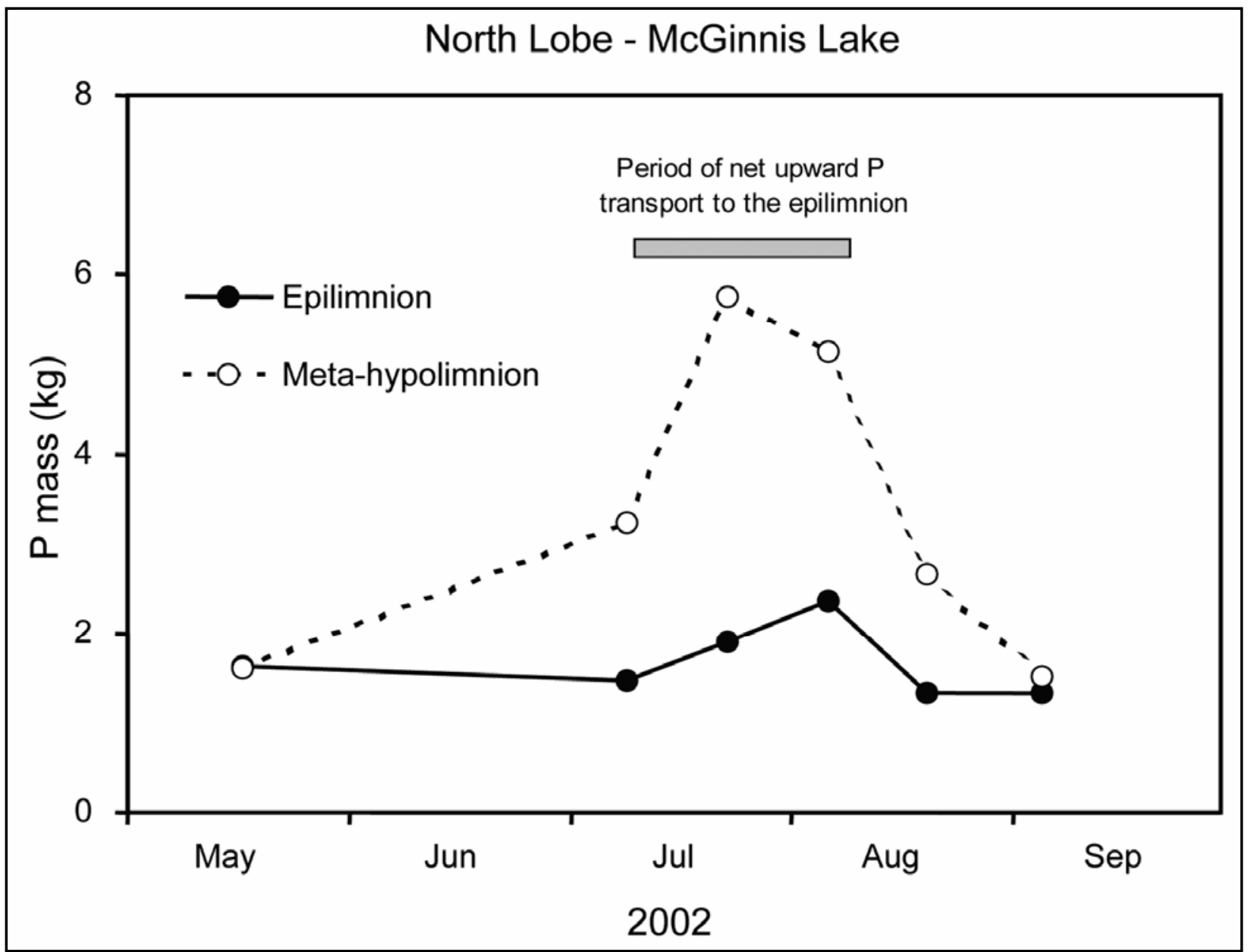

Figure 10. Seasonal variations in phosphorus $(P)$ mass in the epilimnion (i.e., upper $2 \mathrm{~m}$ ) and the metahypolimnion (i.e., water column below the epilimnion) between May and September 2002. The horizontal gray bar represents the period used to calculate net upward $\mathrm{P}$ flux to the epilimnion.

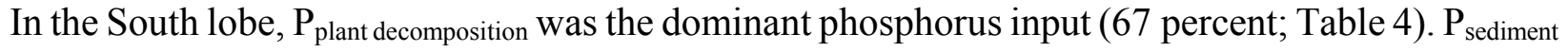
accounted for $\sim 17$ percent and $\mathrm{P}_{\text {precipitation }}$ accounted for $<10$ percent of the total phosphorus input to the South lobe. $\mathrm{P}_{\text {groundwater }}$ inputs were low in the South lobe compared to the North lobe and accounted for only 6 percent of the total phosphorus input to this region of the lake.

Overall, individual phosphorus fluxes to the lake were low relative to internal phosphorus loading estimates determined in some other eutrophic lakes in Wisconsin (James and Barko 1993; James et al. 2000, 2003). However, multiple internal phosphorus sources to each lobe in the summer could contribute to algal blooms. When summed, total internal phosphorus fluxes were $\sim 1 \mathrm{mg} \mathrm{m}^{-2} \mathrm{~d}^{-1}$, which is moderate compared to eutrophic lakes. 
Bathtub Modeling. To evaluate phosphorus loading and water quality response to McGinnis Lake, it was assumed that phosphorus sources from $P$. crispus decomposition and bottom sediment phosphorus release under anoxic conditions could be managed using various techniques (Table 5). $P$. crispus decomposition can be controlled by harvesting biomass before the onset of senescence (James et al. 2003) or by controlling its growth and uptake of sediment phosphorus by pre-emptive management in the fall or spring. Aluminum sulfate, a chemical floc that irreversibly binds sediment phosphorus and removes it from recycling pathways (Cooke et al. 1993), has been used to control phosphorus release from bottom sediments in many eutrophic lakes exhibiting high internal P loading. This management technique might be applicable for control of sediment phosphorus fluxes in McGinnis Lake, particularly the North lobe.

\begin{tabular}{|c|c|}
\hline \multicolumn{2}{|c|}{$\begin{array}{l}\text { Table } 5 \\
\text { Practical Phosphorus Management Techniques for Various } \\
\text { Phosphorus Sources to McGinnis Lake }{ }^{1}\end{array}$} \\
\hline Phosphorus Source & Practical Management Techniques \\
\hline Precipitation & None \\
\hline Groundwater & None \\
\hline P. crispus decomposition & Harvesting, Pre-emption \\
\hline Bottom sediment & Alum salts \\
\hline Overland runoff & BMPs \\
\hline
\end{tabular}

Relative to current conditions, the Bathtub model suggested that total phosphorus, chlorophyll, and Secchi transparency would not improve appreciably in response to a 100 -percent reduction in phosphorus loading from bottom sediments, plant decomposition flux, or a 100-percent reduction in both fluxes (Figure 11). This model response was not surprising because water quality conditions in the surface waters of this lobe are within the mesoeutrophic range and phosphorus inputs to this region from these sources were low. Reductions in groundwater phosphorus inputs, which represented the greatest phosphorus load to the North lobe, would have resulted in improvement over current conditions. However, control of groundwater phosphorus to the lake is probably not feasible.

The model suggested that total phosphorus and chlorophyll concentration could be reduced in the South lobe by 36 percent and 48 percent, respectively, via a 100-percent reduction in $P$. crispus decomposition (Figure 11). Control of sediment phosphorus flux in this region, either separately or in combination with control of $P$. crispus decomposition, did not result in further appreciable improvement. Overall, it appeared that control of $P$. crispus decomposition in the summer represented the most effective phosphorus control management option for improvement of water quality over current conditions in the lake.

The model response of algal bloom concentration and frequency during the summer is shown in Figure 12. Model output indicated that bloom concentration and frequency (percent of time in the summer) were moderate in the lake under current conditions during 2002. As with other water quality indicators, model reductions in bloom frequency and concentration appeared to be greatest when P. crispus decomposition was reduced by 100 percent. Control of sediment phosphorus flux did not appear to affect algal bloom concentration and frequency. The model also suggested that 
improvements in algal bloom concentration and frequency via control of $P$. crispus decomposition would be greatest for the South lobe of the lake, where P. crispus is found in greatest densities.
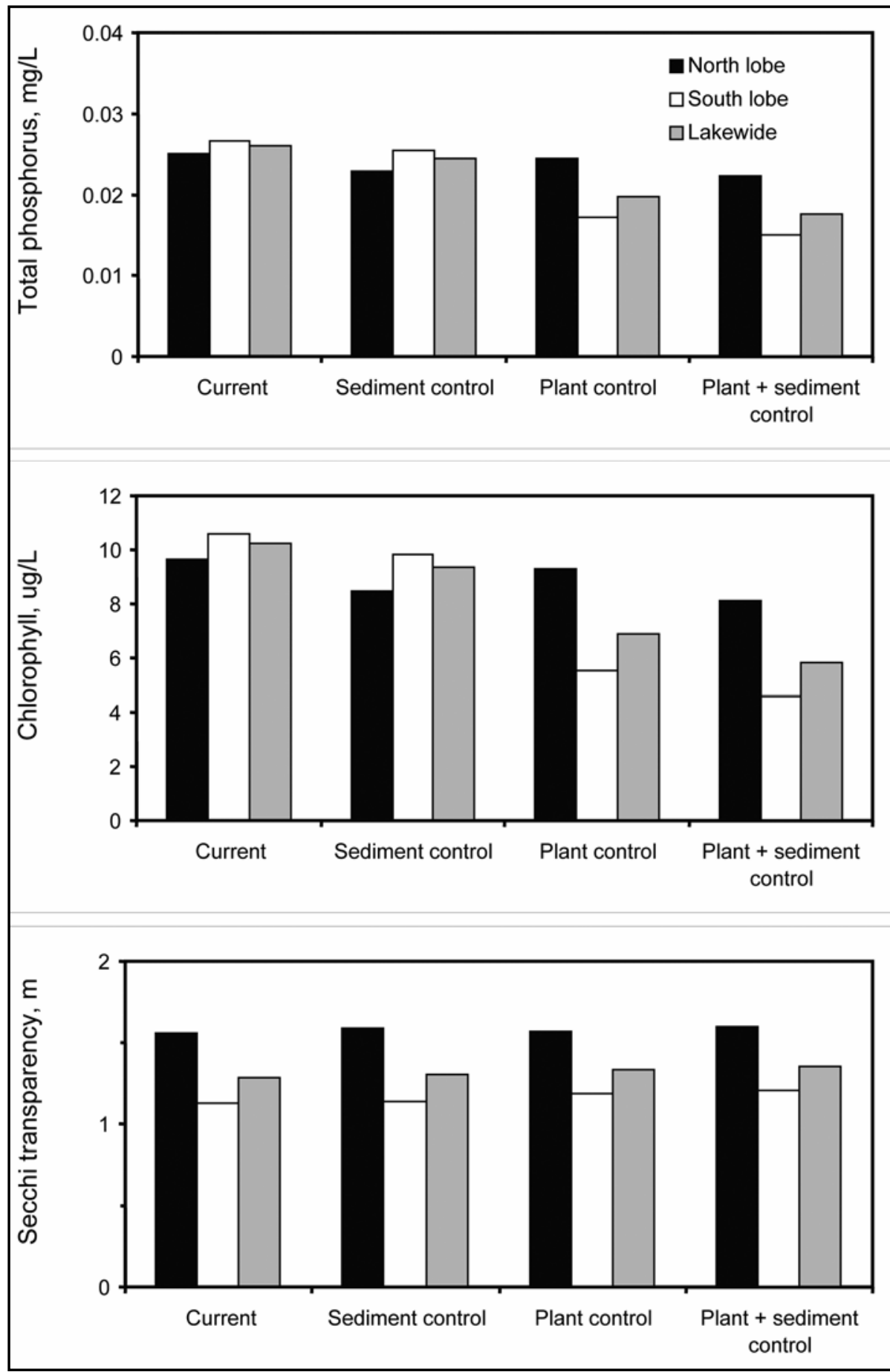

Figure 11. Bathtub model response of total phosphorus, chlorophyll, and Secchi transparency to current phosphorus loading conditions and to control of phosphorus loading from sediments, from plant decomposition, and from both sources. 


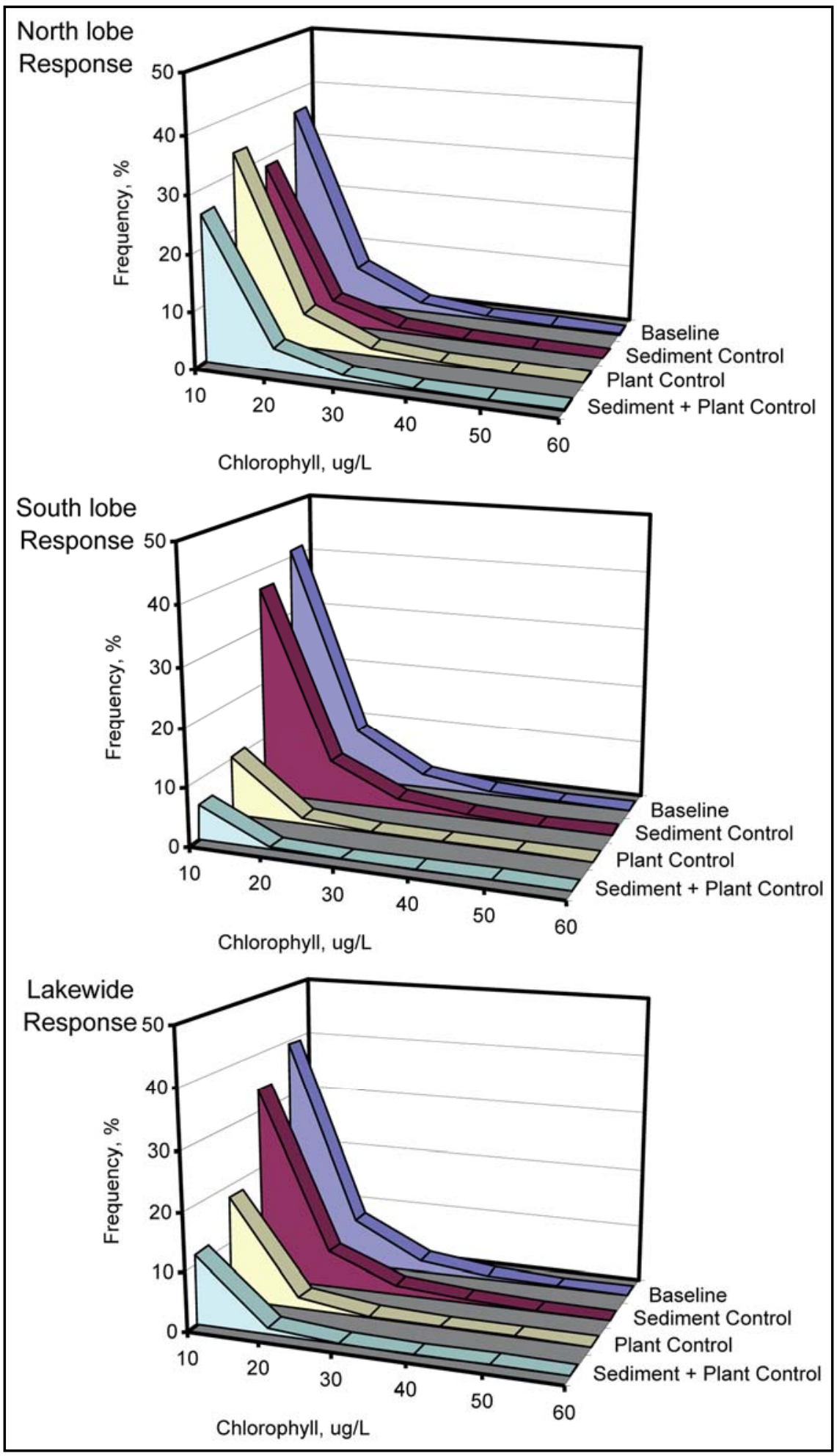

Figure 12. Bathtub model response of bloom frequency (y-axis) and chlorophyll concentrations ( $\mathrm{x}$-axis) to current phosphorus loading conditions and to control of phosphorus loading from sediments, from plant decomposition, and from both sources. 
CONCLUSIONS: Although McGinnis Lake receives multiple internal phosphorus sources during the summer, measured fluxes to the lake were modest and its trophic state index fell within the mesoeutrophic range. Internal phosphorus sources from groundwater and P. crispus decomposition represented the greatest phosphorus inputs to the lake. Although internal P loading from anoxic profundal sediments was high in the North lobe of the lake, we suggest that only a small portion of this phosphorus was transported vertically to the surface waters for uptake by algae. Thermal stratification in the summer most likely restricted upward flux of phosphorus to the epilimnion (Stefan and Hanson 1981).

Model results suggested that removal of $P$. crispus biomass prior to its senescence in the summer could reduce the occurrence and intensity of algal blooms. Control of $P$. crispus biomass can be achieved by harvesting as much as possible before mid-June or by attempting to control its growth in the spring or fall. In contrast, the current results suggest that control of sediment phosphorus fluxes is not necessary at this time.

It also appeared that overland runoff from the watershed and export to the lake was very minor to negligible during the summer period. In many lakes, this source represents an important phosphorus input that can regulate algal growth and result in overfertilization. BMP's (Best Management Practices) and shoreline conservation practices need to be continued in order to prevent watershed fluxes from becoming a problem.

ACKNOWLEDGMENTS: The authors gratefully acknowledge Adams County, The State of Wisconsin, and the U.S. Army Engineer District, St. Paul for providing additional funding for this research; the University of Wisconsin - Stevens Point Environmental Task Force Laboratory for field sampling and analyses of water samples; T. Brunner, M. Daniels, H. Eakin, K. Johnson, L. Pommier, and M. Weiss of the Eau Galle Aquatic Ecology Laboratory for installation and monitoring of gauges on McGinnis Lake outflow and the determination of phosphorus release from the sediments; and D. Soballe and J. Skogerboe for review and improvements to this note. We also thank J. Rous, resident of McGinnis Lake and President of the lake association, for collecting rainfall and lake level information during the study period.

POINTS OF CONTACT: This technical note was written by Mr. William F. James of the Eau Galle Aquatic Ecology Laboratory (EGAEL) of the Environmental Processes and Effects Division (EPED) of the Engineer Research and Development Center (ERDC) and Amy Dechamps, Nancy Turyk, and Paul McGinley of the University of Wisconsin at Stevens Point, Wisconsin, Department of Natural Resources, Stevens Point, Wisconsin. For additional information, contact the manager of the Aquatic Plant Control Research Program, Mr. Robert C. Gunkel (601-634-3722, Robert.C. Gunkel@erdc.usace.army.mil).

This technical note should be cited as follows:

James, W. F., A. DeChamps, N. Turyk, and P. McGinley. 2007. Importance of Potamogeton crispus decay to the phosphorus budget of McGinnis Lake, Wisconsin. APCRP Technical Notes Collection. ERDC/TN APCRP-EA-15. Vicksburg, MS: U.S. Army Engineer Research and Development Center. www.wes.army.mil/el/aqua. 


\section{REFERENCES:}

American Public Health Association (APHA). 1998. Standard methods for the examination of water and wastewater. 20th ed. American Public Health Association, American Water Works Association, Water Environment Federation.

Brock, T. D., D. R. Lee, and D. Winek. 1982. Groundwater seepage as a nutrient source to a drainage lake, Lake Mendota, Wisconsin. Water Research 16: 1253-1255.

Carlson, R. E. 1977. A trophic state index for lakes. Limnology and Oceanography 22:361-36.

Carpenter, S. R. 1980. Enrichment of Lake Wingra, Wisconsin by submerged macrophyte decay. Ecology 61: 11451155.

Cooke, G. D., E. B. Welch, S. A. Peterson, and P. R. Newroth. 1993. Restoration and management of lakes and reservoirs. 2nd edition. CRC Press, Lewis Publishers.

James, W. F., and J. W. Barko. 1993. Analysis of summer phosphorus fluxes within the pelagic zone of Eau Galle Reservoir, Wisconsin. Lake and Reservoir Management 8: 61-71.

James, W. F., and J. W. Barko. 1994. Macrophyte influences on sediment resuspension and export in a shallow impoundment. Lake and Reservoir Management 10: 95-102.

James, W. F., J. W. Barko, and S. J. Field. 1996. Phosphorus mobilization from littoral sediments of an inlet region in Lake Delavan, Wisconsin. Archiv für Hydrobiologie 138: 245-257.

James, W. F., J. W. Barko, H. L. Eakin, and D. R. Helsel. 2000. Distribution of sediment phosphorus pools and fluxes in relation to alum treatment. Journal of the American Water Works Association 36: 647-656.

James, W. F., J. W. Barko, H. L. Eakin, and P. W. Sorge. 2003. Phosphorus budget and management strategies for an urban Wisconsin lake. Lake and Reservoir Management 18: 149-163.

Lillie, R. A., S. Graham, and P. Rasmussen. 1993. Trophic state index equations and regional predictive equations for Wisconsin Lakes. Research Management Findings, No. 35. Madison, WI: Bureau of Research, Wisconsin Department of Natural Resources.

Mortimer, C. H. 1971. Chemical exchanges between sediments and water in the Great Lakes - speculations on probable regulatory mechanisms. Limnology and Oceanography 16: 387-404.

Stefan, H. G., and M. J. Hanson. 1981. Phosphorus recycling in five shallow lakes. ASCE Journal of Environmental Engineering 107: 713-730.

Walker, W. W. 1996. Simplified procedures for eutrophication assessment and prediction: User manual. Instruction Report W-96-2. Vicksburg, MS: U.S. Army Engineer Waterways Experiment Station.

NOTE: The contents of this technical note are not to be used for advertising, publication

or promotional purposes. Citation of trade names does not constitute an official endorsement or approval of the use of such products. 